\title{
The Role of Public Goods Provision in Reducing Poverty in Sub-Saharan Africa: Quantile Regression and Fixed Effect Models
}

\author{
Owusu Samuel Mensah ${ }^{1}$, Hu Qioํㅜ, Fu Chuambo', Ellen Merz ${ }^{2}$ \\ ${ }^{1}$ School of Business, Jinggangshan University, Ji'an, China \\ ${ }^{2}$ School of Foreign Languages, Jinggangshan University, Ji'an, China \\ Email: *omensju15@yahoo.com
}

How to cite this paper: Mensah, O.S., Qio, H., Chuambo, F. and Merz, E. (2021) The Role of Public Goods Provision in Reducing Poverty in Sub-Saharan Africa: Quantile Regression and Fixed Effect Models. Open Access Library Journal, 8: e8129. https://doi.org/10.4236/oalib.1108129

Received: October 27, 2021

Accepted: November 27, 2021

Published: November 30, 2021

Copyright $\odot 2021$ by author(s) and Open Access Library Inc.

This work is licensed under the Creative Commons Attribution International License (CC BY 4.0).

http://creativecommons.org/licenses/by/4.0/

\section{(c) (i) Open Access}

\begin{abstract}
The poverty situation in sub-Saharan Africa continues to be a major concern to the world due to the increasing rate of population. The study investigates the impact of institutional investments on poverty reduction in sub-Saharan Africa using panel data from 2000-2018. The study employed fixed effect and quantile regression models to investigate the relationship between institutional investment and poverty reduction. The results revealed that investment in education contributes significantly to the fight against poverty in the subregion as compared to health investment. Also, investment in the energy sector also contributes significantly to the fight against poverty in the sub-region, however, the security investment has no significant effect on poverty reduction. The results from the quintile regression confirm the earlier results. In conclusion, the study discovered that investing in infrastructure, health, energy, technology, sanitation, and water supply, and education sectors in the sub-region has a consequential effect on poverty reduction in the sub-region.
\end{abstract}

\section{Subject Areas \\ Public Policy}

\section{Keywords}

Poverty Alleviation, Public Goods, Quantile Regression, Fixed Effect Model, Sub-Saharan Africa

\section{Introduction}

Public goods supply has become a tool for socio-economic development in both 
developed and less developed countries. Therefore, with the drive to reduce the high level of poverty in the region, it is necessary for the various governments and other stakeholders to effectively utilize national resources and ensure their equitable distribution (Fosu \& Gafa, 2020) [1]. According to Ostrom and Ostrom (2019) [2] public goods are consumable goods commonly enjoyed by all and the consumption of such goods should not cause its reduction or subtraction. Much has been said on a fair distribution of public goods; however, the bone of contention has been whether its provision will have any impact on poverty reduction, especially in sub-Saharan Africa countries.

Despite the significant progress in achieving the Sustainable Development Goal of ending extreme poverty by 2030, poverty reduction in sub-Saharan Africa is still a challenge to the leaders and in the sub-region. Thus, public goods provision plays a major role when poverty reduction is concerned in sub-Saharan Africa. According to the United Nations Deputy Secretary-General's report at the opening of 2017 Integrated Segment of the UN Economic and Social Council (ECOSOC), "there is the need for the formulation and implementation of coherent and integrated approaches at the regional, national and global level by policymakers across the globe to eradicate poverty, more especially in African and Asian continents".

The national governments need to take the responsibility of providing some basic needs such as financial stability, quality air, peace, and cultural heritage to their people and their commitment to the sub-region should be significant enough to fight against the high level of poverty. However, notwithstanding the efforts and measures put in place by some developing countries in sub-Sahara Africa to achieve the Sustainable Development Goal of ending extreme poverty by 2030 , the high rate of corruption coupled with weak institutional policies has become major setbacks to the fight against poverty.

According to Deneulin and Townsend (2007) [3], the high level of corruption and resource constraints to enforce regulations for formal institutions to effectively carry on their duties has crippled the governments to ensure effective provision of public goods to improve the wellbeing of the people. As reported by Tsai (2007) [4], weak and ineffective formal institutions in developing countries have made it very difficult for the various institutions to control the high rate of corruption. This study focuses on public goods provision in some selected countries in sub-Saharan Africa and their consequential effect on poverty reduction.

Figure 1 shows the projection to 2030 for the major countries in the world with the most extreme poor in 2015.

The annually published report by the Organization for Economic Co-operation and Development (OECD) revealed that the recent reduction of income of people in low-income families and the high dependency ratio have increased the rate of poverty in the region. The goal of ending poverty by 2030 as stated by the United Nations Agenda for Sustainable Deadline has been very significant in addressing these issues through the concerted effort putting in to achieve the 


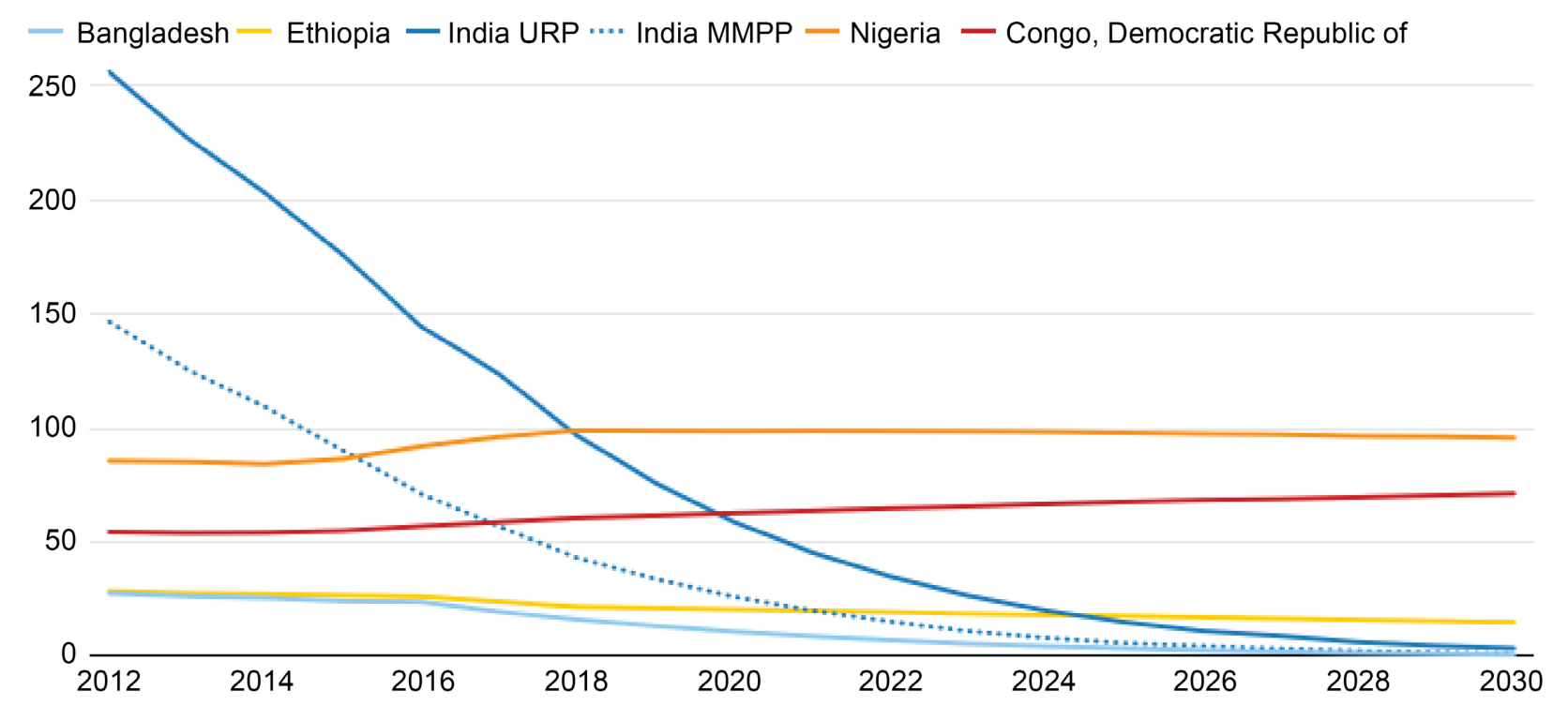

Figure 1. Projections to 2030 for the five countries with the most extreme poor in 2015. Note: India URP (Uniform Reference Period) relies on poverty estimates and projections based on a uniform recall period; India MMRP (Modified Mixed Reference period) relies on poverty estimates and projections based on the modified mixed recall period. Source: World Bank Database (http://wrld.bg/km0y50tjUfO).

goal before 2030. The World Economic Forum's 2018 reported that the increasing rate of poverty in sub-Saharan Africa has been very alarming with the people living below $\$ 1.90$ making it difficult to meet the global target of ending extreme poverty by 2030 .

Figure 2, however, emphasis on the regional distribution of poverty across the globe. The report from World Bank further disclosed that the average rate of poverty in sub-Saharan Africa stands at 41 percent, and out of the listed 28 countries are in abject poverty worldwide, 27 of them with a poverty rate above 30 percent come from Africa. Moreover, the fight against poverty in sub-Saharan Africa as compared to the countries in the Eastern and Southern parts of Asia has not been the best as reported (Figure 2).

The rest of the paper is organized as follows. Section 2 talks about the related literature. Section 3 talks about data and empirical methodology. Section 4 talks about empirical results and discussion. Section 5 concludes.

\section{Literature Review}

A report from the Worldbank revealed that out of the 736 million people who lived in extreme poverty in 2015, 368 million, which is about 50 percent lived in only five countries as shown in Figure 3. However, according to World Bank tackling poverty among the people in these five countries will have a far-reaching effect on poverty reduction (people living on less than $\$ 1.90$ a day) to about 3 percent as predicted. The development of human capital in sub-Saharan Africa through public investment has been a major concern to policymakers for decades (Danquah \& Amankwah-Amoah, 2017) [5]. Though public 
1990

In this chart, area is proportional

to population. The world's

population grew from 5.3 billion

in 1990 to 7.2 billion in 2013.

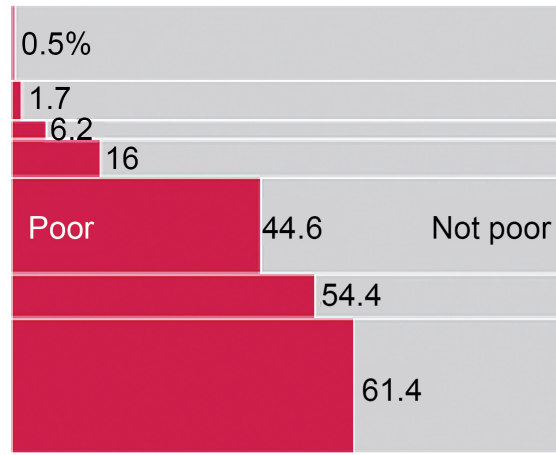

$0 \quad 25 \quad 50$
The percentage of people living in extreme poverty

in Sub-Saharan Africa has fallen, but the number of extremely poor people in the region has grown.

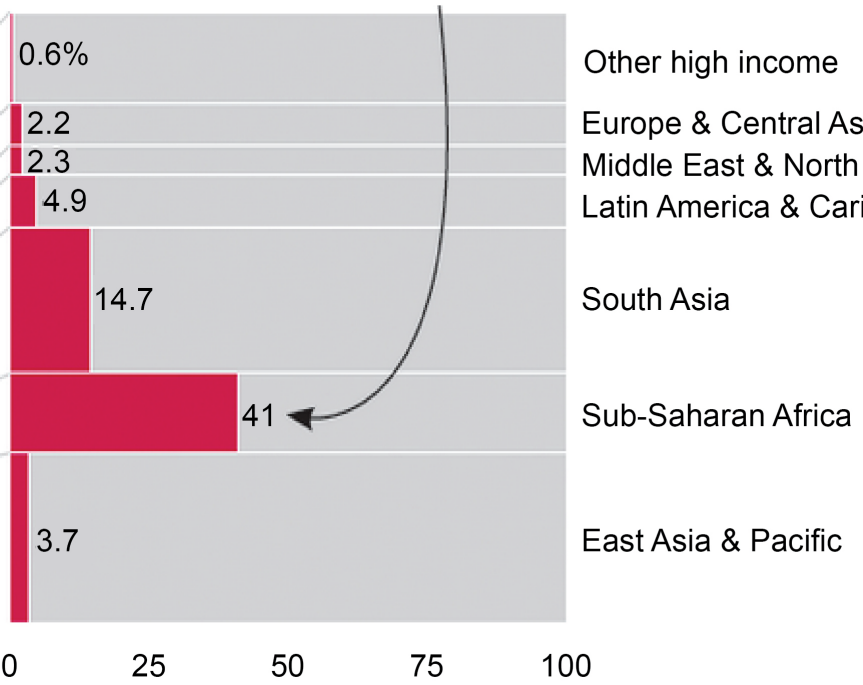

Share of population (\%)

Figure 2. Regional Distribution of Poverty in Sub-Saharan Africa, South Asia and East Asia \& Pacific. Note: Poor refers to people living on less than $\$ 1.90$ a day (2011PPP). Regional aggregates exclude certain high-income countries. Source: World Bank Database 2015 .
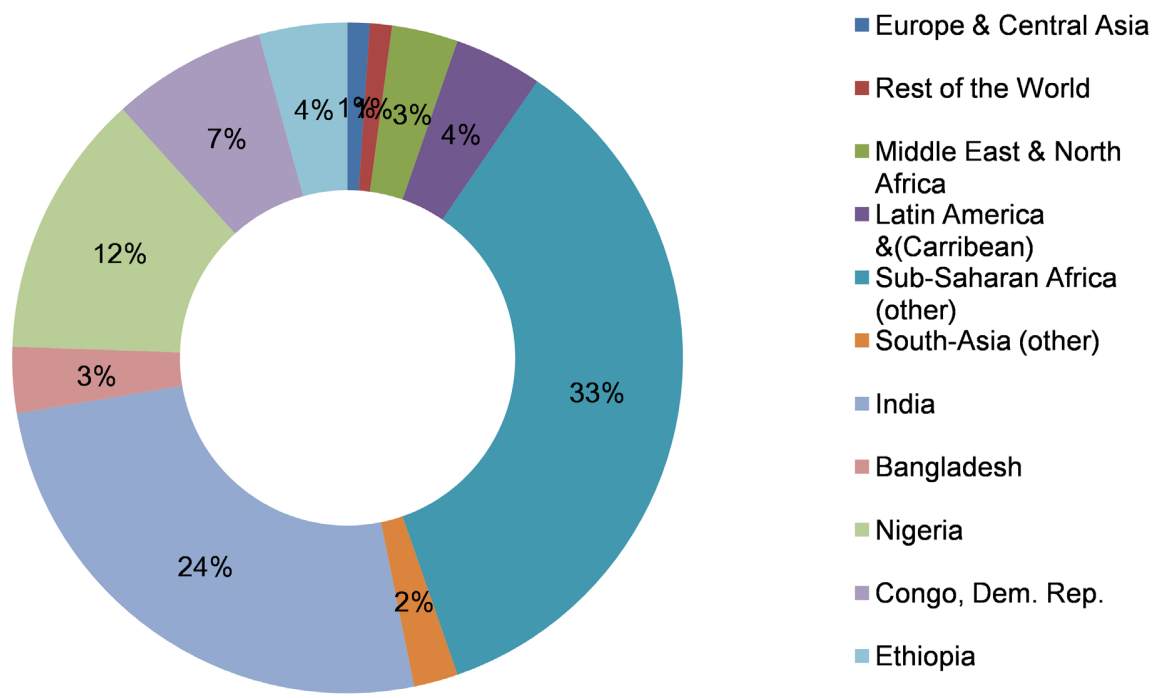

Figure 3. Share of poor people in the world by region or country, 2015. Source: Authors' construct (World Bank Database (http://wrld.bg/km0y50tjUfO).

expenditure in the region has increased significantly, stakeholders have raised concerns over the impact of these investments on socio-economic development. That is the investment should be translated into addressing and eradicating the high level of poverty in the sub-region. Poverty in African and other developing nations has been a major issue for several decades. Several studies conducted have attributed it to unfavorable weather conditions, economic mismanagement, 
conflicts, and lack of goodwill on the side of the leaders. According to United Nations Deputy Secretary-General, Amina Mohammed at the opening of the 2017 Integrated Segment of the UN Economic and Social Council (ECOSOC), "Addressing poverty, inequality, climate change, food security, and a sluggish and unpredictable global economy requires integrated responses and engagements by all actors. "Ms. Mohammed further stated that "Poverty eradication is an indispensable requirement for sustainable development".

A study conducted by Domeher and Abdulai (2012) [6], attributed the high level of poverty on the continent to the lack of inappropriate agro-based infrastructure, water and electricity, and the deprived state of socioeconomic activities such as transport and telecommunication network. Moreover, shoddy and inflated projects in the course of providing social-economic infrastructure and lack of proper investment in supporting the supplies of public service and goods have also contributed to the high poverty rate in the sub-region(Nguyen \& Trinh, 2018) [7]. Although massive investments have been made in the sub-region, whether these investments are achieving the goal of poverty reduction has been questioned due to the number of people still living on less than $\$ 1.90$ a day in SSA.

A study conducted by Diga, Nwaiwu, and Plantinga (2013) [8], on ICT policy and poverty reduction in Africa, revealed that focusing on ICT policy interventions continues to play a significant role in poverty reduction. Besides, Ameyaw Domfeh and Nyigmah Bawole (2009) [9] examined poverty reduction at the local level in Ghana. The study disclosed that although many poverty reduction initiatives have improved the living conditions of many people, the policies should be extended to several areas and several people across the country. The study further suggested that to fully achieve the goal of reducing poverty among people in the poorest communities in the country, the poverty reduction policies should be designed to factor in the people who are the direct beneficiaries of the poverty alleviation policies. Ohiorhenuan (2011) [10] also conducted a study focusing on the future of poverty and development in Africa. The findings revealed that African leaders should replace the poverty ideology as perceived by the international community with one of prosperity.

Another study conducted by Denby Wilkes (2005) [11] investigated the relationship between energy production and poverty and the results revealed that making energy accessible to people in the deprived areas on the continent will lead to rural electrification and development of local economic activities. The study, therefore proposed that working in less developed areas comes with some challenges such as unsustainable power supply, establishing local business zones with higher power levels, and ensuring maximum equipment will ensure rural industrialization and promote development. Abubakar (2015) [12] also maintained that entrepreneurship development is a tool for poverty reduction in sub-Saharan Africa. Luiz (2006) [13] also conducted a study on the wealth and poverty level in sub-Saharan Africa and the findings revealed that the high level 
of poverty in sub-Saharan Africa is attributed to bad luck, initial conditions, and unfavorable international economic activities. A study conducted by Adetunji Babatunde, Oyeranti, Bankole, and Olawale Ogunkola (2012) [14] maintained that there is no significant relationship between oil export in Africa countries and poverty reduction. Using AEDL to investigate the relationship between infrastructure development and poverty reduction, the study revealed both the long run and the short-run relationship between infrastructure development and poverty reduction. The causality test of the study further confirmed a positive and unidirectional causality running from infrastructure development to poverty reduction (Chotia \& Rao, 2017) [15].

\section{Methodology}

\subsection{Data Source and Variable Specification}

The study employed unbalanced panel data of 8 West African countries over the period of 2007-2019. This section explains the various variables use for the study. According to the World Bank, the sub-Saharan Africa's economy grew from $2.4 \%$ in 2017 to $3.2 \%$ in 2018, and the growth was projected to be $3.5 \%$ in 2019. Data from the World Bank database is adopted to estimate the government investments and their impact on poverty reduction in eight west African countries, namely; Senegal, Côte d'Ivoire, Burkina Faso, Togo, Nigeria, Mauritania, Benin, and Ghana. Ghana, according to the World Bank report in 2018 was the fastest growing economy in Africa. The economies of Senegal, Côte d'Ivoire, and Benin also performed creditably well in 2018 and they are expected to perform better in the following year. These countries' Human Development Index (HDI) has also increased significantly [16].

Poverty is measured by the international poverty line of US $\$ 1.90 /$ day per person proposed by the World Bank. The explanatory variables used for the study are government investments in health, education, electricity consumption,

Table 1. Variable definition and data source.

\begin{tabular}{|c|c|c|}
\hline Variables definitions & Operational definition & Data Source \\
\hline Poverty $(\mathrm{P})$ & $\begin{array}{l}\text { Poverty headcount ratio at } \$ 1.90 / \\
\text { a day (2011 PPP) }\end{array}$ & World Bank database \\
\hline Health $^{\mathrm{n}}$ & $\begin{array}{l}\text { Domestic general government } \\
\text { health expenditure ( } \% \text { of GDP) }\end{array}$ & World Bank database \\
\hline Education $^{\mathrm{n}}$ & $\begin{array}{l}\text { Government expenditure on } \\
\text { education, total ( } \% \text { of GDP) }\end{array}$ & World Bank database \\
\hline Electricity $^{\mathrm{n}}$ & $\begin{array}{l}\text { Energy use kg of oil equivalent per } \\
\quad \$ 1,000 \text { GDP (2011 PP) }\end{array}$ & World Bank database \\
\hline Security $^{\mathrm{n}}$ & Military expenditure (\% of GDP) & World Bank database \\
\hline
\end{tabular}

Notes: ${ }^{\mathrm{n}}$ Variables are converted into their natural logarithm to ensure normal distribution of the data. 
and security (Table 1). Health variable used domestic general government health expenditure (\% of GDP) as a proxy, education is represented by government expenditure on education, total (\% of GDP), provision of electricity used electric power consumption (kWh per capita) as a proxy, and security is measured by Military expenditure (\% of GDP).

\subsection{Empirical Approach}

Panel data from 2007-2018 from the World Bank database is adopted to examine the impact of public goods on poverty reduction in sub-Saharan Africa. The study further adopted the fixed effect model and quantile regression model to investigate the relationship between public goods provision and poverty reduction. The individual effects model is presented as follows:

$$
G_{i t}=\alpha_{i}+R_{i t} \gamma+\varepsilon_{i t} i=1,2, \cdots, P ; t=1,2, \cdots, M
$$

where $i$ represents the various countries captured in the model, $t$ representing time in the model. $\alpha$ denotes the individual intercept, $\gamma$ is $\kappa \times 1$ and $R_{i t}$ the it th observation on $K$ explanatory variables.

The fixed effect model is, therefore, model as:

$$
G_{i t}=\gamma_{0}+\gamma_{1} R_{1, i t}+\cdots+\gamma_{k} R_{k, i t}+G_{2} N_{2}+\cdots+\Phi_{t} T_{t}+\varepsilon_{i t}
$$

where $G_{i t}$ in the dependent variable, $i=$ entity and $t=$ time. $R_{k, i t}$ represents the independent variables, $\gamma_{k}$ represents the coefficient for the independent variables, $\varepsilon_{i t}$ is the error term, $N_{2}$ is the entity n, $G_{2}$ denotes the coefficient for the binary entities, $T_{t}$ is the time and $\Phi_{t}$ denotes the coefficient of the for the binary time regression. Therefore, with the random model, the individual effect is treated as a random component and part of the error structure, not the intercept. The random-effect model is therefore written as:

$$
G_{i t}=\gamma R_{i t}+\alpha+u_{i t}+\varepsilon_{i t}
$$

Random effects assume assumes that the entity's error term is not correlated with the predictor which allows for time-invariant variables to play a role as explanatory variables. The individual effect in the random effect is treated as a random component and part of the errors structure, not the intercept. Panel data takes into consideration the individual heterogeneity, allows a greater representation of the data, and improves the efficiency of the estimates. The period 2007-2018 is so limited that there is no need to run for the correlation matrix of residual test because the data is unlikely to be prone to the problem of autocorrelation.

\section{Empirical Results and Discussion}

\subsection{Unit Root Test}

Since the study adopted panel data from different countries, unit root test is used to test for the data stationarity. The study used Levin-Lin-Chu test [17], and Hadri LM test [18] and the results are summarized in Table 2. 


\subsection{Empirical Results}

The mean and median of all variables used for the study are summarized in Table 3 below and fall within the maximum and minimum values. About $40 \%$ of the variables are skewed positively. From Table 3 health and security are positively skewed while poverty, education, and electricity are negatively skewed. Table 3 further reports the values of the Jarque-Bera and their p-values of the coefficients, which are less than 5\% significant level, implying that the null hypothesis reporting the normality of the various variables used for the study are not rejected.

The results of the study are presented in Table 4 and Table 5. Table 4 reports the results of the pooled regression model, fixed effect, and random-effect model for comparison. With the diagnostic test of the OLS pooled regression model all the variables were pooled together to run the model ignoring the cross and the

Table 2. Panel unit root test.

\begin{tabular}{cccccc}
\hline & Poverty & Health & Education & Electricity & Security \\
\hline Levin-Lin-Chu test & & & & & \\
Level & 1.601 & -0.989 & 0.141 & 1.7636 & -0.406 \\
$\begin{array}{c}\text { Difference } \\
\text { Hadri LM test }\end{array}$ & $-1.273^{*}$ & $-1.958^{* *}$ & $-2.927^{\star * *}$ & $2.574^{*}$ & $-0.179^{*}$ \\
Level & $16.420^{* * *}$ & $9.807^{\star * *}$ & $1.447^{* *}$ & $0.004^{*}$ & $8.983^{* * *}$ \\
Difference & -1.214 & -0.676 & $1.737^{\star *}$ & $1.905^{\star *}$ & -0.617 \\
\hline
\end{tabular}

Table 3. Descriptive statistics, correlation matrix and diagnostic test.

\begin{tabular}{cccccc}
\hline & Poverty & Health & Education & Electricity & Security \\
\hline Mean & 22.45682 & 19.25347 & 7.09253 & 139.8786 & 2.182275 \\
Median & 21.75 & 5.872606 & 4.844106 & 151.4272 & 1.563143 \\
Maximum & 45.1 & 121.7331 & 43.43308 & 511.4585 & 7.43594 \\
Minimum & 9.1 & 3.5993 & 2.88869 & 4.748144 & 0.37105 \\
Std. Dev. & 7.854273 & 26.60523 & 8.689172 & 119.2582 & 1.994316 \\
Skewness & -0.46703 & 2.279179 & -3.639592 & -0.549313 & 1.438207 \\
Kurtosis & 2.67047 & 7.737124 & 14.71588 & 2.618438 & 3.487897 \\
Jarque-Bera & 3.597213 & 158.4696 & 697.5774 & 4.959415 & 31.20995 \\
Probability & 0.165529 & 0.0000 & 0.00000 & 0.083768 & 0.00000 \\
Sum & 1976.2 & 1694.305 & 624.1426 & 12309.32 & 192.0402 \\
Sum Sq. Dev. & 5366.996 & 61581.91 & 6568.648 & 1237358 & 346.0248 \\
Observations & 96 & 96 & 96 & 96 & 96 \\
\hline
\end{tabular}


Table 4. General results of estimating the relationship between public goods provision and poverty reduction.

\begin{tabular}{cccc}
\hline Independent variable & Pooled Regression & Fixed Effect & Random Effect \\
\hline Health & -0.072 & -0.001 & -0.072 \\
& $(0.000)$ & $(0.072)$ & $(0.512)$ \\
Education & -0.018 & -0.523 & 0.019 \\
Electricity & $(0.000)$ & $(0.000)$ & $(0.000)$ \\
Security & 0.028 & -0.041 & 0.029 \\
& $(0.065)$ & $(0.036)$ & $(0.056)$ \\
Constant & -0.070 & 0.078 & 0.070 \\
& $(0.002)$ & $(0.001)$ & $(0.001)$ \\
F-value & 0.669 & -0.166 & 0.668 \\
& $(0.000)$ & $(0.136)$ & $(0.000)$ \\
Hauseman text (P-value) & 16.67 & 53.08 & 66.6 \\
R & $(0.000)$ & $(0.000)$ & $(0.000)$ \\
Obs. & & 0.012 & \\
\hline
\end{tabular}

Notes: ${ }^{\star}$ Statistical significance at $0.10,{ }^{* *}$ Statistical significance at $0.05,{ }^{* *}$ Statistical significance at 0.01 .

Table 5. Quantile Regression results for the selected countries in West Africa.

\begin{tabular}{ccccccc}
\hline Variables & Q.15 & Q.30 & Q.45 & Q.60 & Q.75 & Q.90 \\
\hline Health & $-0.105^{\star * *}$ & $-0.522^{* *}$ & $-0.216^{* * *}$ & 0.033 & -0.003 & $0.024^{\star *}$ \\
Education & -0.035 & $-0.007^{\star}$ & $-1.194^{\star *}$ & $-0.333^{*}$ & $0.110^{* *}$ & $-0.433^{\star * *}$ \\
Electricity & $-0.004^{* *}$ & $-0.017^{\star}$ & 1.279 & 0.358 & 2.155 & $1.282^{\star}$ \\
Security & $-0.114^{\star}$ & 0.057 & $-0.071^{\star}$ & 0.046 & $0.185^{\star}$ & 0.635 \\
Pseudo $\mathrm{R}^{2}$ & 0.4552 & 0.5175 & 0.6206 & 0.7221 & 0.8615 & 0.7013 \\
\hline
\end{tabular}

Notes: ${ }^{\star}$ Statistical significance at $0.10,{ }^{*}$ Statistical significance at $0.05,{ }^{* *}$ Statistical significance at 0.01 .

time-series nature of data. The pooled regression model moreover, does not distinguish between the various countries used for the study. Therefore, by combining all the countries through pool regression we reject the heterogeneity that may be presence among the countries and treat all the countries cannot be the same all the time.

From Table 4, though the pooled regression results cannot be accepted since the countries used for the study are not the same, all the variables were statistically significant at $5 \%$ level. The results from Table 4 show that governments' investment in the health sector had a mild but significant effect on the reduction of poverty in the sub-region.

Several studies have come out with the problems in connection with the health 
investment in African countries. According to Jalloh [19] despite the various policies implemented by the leaders on the continent, there is a problem with the dissemination of information. The study revealed that most of the countries in sub-Saharan Africa need the required information and materials to guide the health policies and programs for effective health care delivery. However, the massive health investment in Africa can only translate into poverty reduction if the sub-region prioritizes health promotion and disease prevention, increased use of information, education, and communication. According to Quaye [20], the inefficient nature of medical technology in the general planning of health cases in Africa, unnecessary use of drugs, lack of proper medical insurance to supplement the high medical cost, weak institutions to check the importation and sales of harmful and expired drugs, and inadequate health resources are major causes of a disproportionate high burden of disease, disability, Andrew J. Macnab, Donald Stewart [21], and premature death and high level of poverty in the sub-region.

To achieve universal primary education and over 40 million children reported to be out of school in sub-Saharan Africa, the continent has increased its investment in the educational sector [22]. The result from Table 4 indicates that governments' expenditure on education had the largest impact on poverty reduction. The significant effect of education could be attributed to the government's effort in the sub-region to channel the greater percentage of the country's GDP into the educational sector. This has been necessitated by the growing number of the youthful population across the continent with about 50 percent under the age of 15 . However, despite the massive investment in the sub-region, no Africa country has achieved "universal primary education" [23]. Therefore, for sustainable growth in the sub-region, there is the need to redirect the resources to promoting quality education and training of the young people with the technological skills needed. Moreover, the strengthening of the educational institutions in the sub-region needs the concerted effort of the policy-makers, educators, administrators, philanthropists, and other groups interested in capacity building to address the various issues facing the sector [23]. According to Psacharopoulos [24], investment in primary education in both developed and less developed countries has become critical due to its role in developing human capital. The results from Table 4 revealed that the impact of educational investment on poverty reduction is positive and the coefficient is statistically significant supporting several studies conducted [25] [26].

The study further investigated the relationship between reliable electricity and poverty reduction in the sub-region. The results from Table 4 however, revealed that governments' spending on electricity had a substantial impact on poverty reduction in the sub-region within the study period. The study revealed that energy efficiency in West African countries has significantly increased the standard of living of the people in the sub-region. However, Russell [27] maintains that countries that fail to improve energy efficiency forfeit business earnings, 
which slow down socioeconomic development and render the people very poor.

The state of the national security and ensuring a secured environment to attract both foreign and local investors to West African countries has been a matter of importance to many stakeholders because of its role in job creation [28]. Several studies concerning security issues in African countries have equated the high level of poverty in the region to the state of insecurity. Therefore, promoting peace on the continent has a consequential effect on poverty reduction in the sub-region. According to the study, improving and strengthening the security regions in the selected countries in West Africa had no impact on reducing poverty in the sub-region [29]. This means that the insecurity in the major parts of the sub-region is affecting job issues, which is worsening the poverty situation in the sub-region.

A study conducted by Brainard, Chollet, and LaFleur [30] revealed cause effect relationship between poverty and insecurity in African countries.

Table 5 shows the percentiles $15^{\text {th }}, 30^{\text {th }}, 45^{\text {th }}, 60^{\text {th }}, 75^{\text {th }}$, and $90^{\text {th }}$. The results presented in Table 5 demonstrate that the pseudo- $\mathrm{R}^{2}$ varies quantile by quantile and is generally smaller for the lower quantile points distribution than the higher quantiles of distribution. The values of the pseudo- $\mathrm{R}^{2}$ are between about $40 \%$ and close to $80 \%$ which means that the considered predicators explained the variance at different levels of poverty distribution. Therefore, the evaluation of the model implies that it is not weak at all quantiles. Furthermore, the study chooses the $90^{\text {th }}$ quantile regression model because it provides the highest pseudo- $\mathrm{R}^{2}$. The study finally estimates all the quantile regression considered in the study.

The results in Table 5 for the different quantiles show that the magnitude of the coefficients changes as we move along the poverty distribution points. The coefficients for health are higher and significant at the lower quantiles of the distribution indicating the role that health investment has been playing in reducing poverty in the sub-region, which confirms the findings from Table 4. Moreover, for investment in education, Table 5 indicates that the coefficient on the poverty reduction is negative at all quantiles, suggesting evidence of conditional convergence. For instance, for the $15^{\text {th }}$ quantile, the coefficient on poverty reduction is -0.035 while for the $90^{\text {th }}$ quantile the coefficient is -0.433 . Again, the effect of electricity provision on poverty reduction according to the quantile is positive and significant at the lower quantile of the distribution, which is different at the higher quantile of the distribution. The coefficients of the security in the subregion from Table 5 do not have any significant impact on the state of poverty in the sub-region.

\section{Conclusion}

Equitable investment in the various sectors of the Africa economy continues to have a significant impact on poverty reduction. The paper discusses the contribution of public goods in achieving the Sustainable Development Goal of ending extreme poverty in some selected countries in sub-Saharan Africa. The study 
adopted a panel data technique from 2000 to 2018 for the analysis. This study is necessitated by the level of poverty among some of the fastest developing countries in the sub-region. According to a World Bank report released in early 2020, Ghana, Ethiopia, Côte d'Ivoire, Senegal, Tanzania, Sierra Leone, Burkina Faso, Benin, Rwanda, and Niger in sub-Saharan Africa sought significant growth in their economies with the GDP ranging from 5.2 to 8.3 percent in 2018. The results from the macro-level revealed an investment in education as the means to fight poverty in the sub-region. Moreover, from the selected countries, the results revealed that investment in education performed creditably well in achieving the Sustainable Development Goal of ending extreme poverty in the sub-region however, the investment in providing an effective healthcare system performed poorly in dealing with the canker. The study, however, made several recommendations to the stakeholders and policymakers, which will go a long in achieving the Sustainable Development Goal of ending extreme poverty in the sub-region by 2030 .

\section{Conflicts of Interest}

The authors declare no conflicts of interest.

\section{References}

[1] Fosu, A.K. and Gafa, D.W. (2020) Progress on Poverty in Africa: How Have Growth and Inequality Mattered? African Review of Economics and Finance, 12, 61-101.

[2] Ostrom, V. and Ostrom, E. (2019) Public Goods and Public Choices. In: Savas, E.S., Ed., Alternatives for Delivering Public Services, Routledge, New York. https://doi.org/10.4324/9780429047978-2

[3] Deneulin, S. and Townsend, N. (2007) Public Goods, Global Public Goods and the Common Good. International Journal of Social Economics, 34, 19-36. https://doi.org/10.1108/03068290710723345

[4] Tsai, L.L. (2007) Solidary Groups, Informal Accountability, and Local Public Goods Provision in Rural China. American Political Science Review, 101, 355-372. https://doi.org/10.1017/S0003055407070153

[5] Danquah, M. and Amankwah-Amoah, J. (2017) Assessing the Relationships between Human Capital, Innovation and Technology Adoption: Evidence from Sub-Saharan Africa. Technological Forecasting and Social Change, 122, 24-33. https://doi.org/10.1016/j.techfore.2017.04.021

[6] Domeher, D. and Abdulai, R. (2012) Land Registration, Credit and Agricultural Investment in Africa. Agricultural Finance Review, 72, 87-103. https://doi.org/10.1108/00021461211222141

[7] Nguyen, C.T. and Trinh, L.T. (2018) The Impacts of Public Investment on Private Investment and Economic Growth: Evidence from Vietnam. Journal of Asian Business and Economic Studies, 25, 15-32. https://doi.org/10.1108/JABES-04-2018-0003

[8] Diga, K., Nwaiwu, F. And Plantinga, P. (2013) ICT Policy and Poverty Reduction in Africa. Info, 15, 114-127. https://doi.org/10.1108/info-05-2013-0032

[9] Ameyaw Domfeh, K. and Nyigmah Bawole, J. (2009) Localising and Sustaining Poverty Reduction: Experiences from Ghana. Management of Environmental Quality, 20, 490-505. https://doi.org/10.1108/14777830910981186 
[10] Ohiorhenuan, J.F.E. (2011) The Future of Poverty and Development in Africa. Foresight, 13, 7-23. https://doi.org/10.1108/14636681111138730

[11] Denby Wilkes, V. (2005) Dealing with a Global Issue: Contributing to Poverty Alleviation. Corporate Governance: The International Journal of Business in Society, 5, 61-69. https://doi.org/10.1108/14720700510604706

[12] Abubakar, H.A. (2015) Entrepreneurship Development and Financial Literacy in Africa. World Journal of Entrepreneurship, Management and Sustainable Development, 11, 281-294. https://doi.org/10.1108/WJEMSD-04-2015-0020

[13] Luiz, J.M. (2006) The Wealth of Some and the Poverty of Sub Saharan Africa. International Journal of Social Economics, 33, 625-648.

https://doi.org/10.1108/03068290610683422

[14] Adetunji Babatunde, M., Oyeranti, O.A., Bankole, A.S. and Olawale Ogunkola, E. (2012) Exports Trade, Employment and Poverty Reduction in Nigeria. International Journal of Social Economics, 39, 875-899. https://doi.org/10.1108/03068291211263916

[15] Chotia, V. and Rao, N.V.M. (2017) An Empirical Investigation of the Link between Infrastructure Development and Poverty Reduction: The Case of India. International Journal of Social Economics, 44, 1906-1918. https://doi.org/10.1108/IJSE-06-2016-0154

[16] Pervaiz, R. and Faisal, F. (2017) Cancer Incidence and Mortality Are Associated with Human Development Index and Health Setups in Africa. Journal of the Egyptian National Cancer Institute, 29, 123-126. https://doi.org/10.1016/j.jnci.2017.05.003

[17] Levin, A., Lin, C.F. and Chu, C. (2002) Unit Root Test in Panel Data: Asymtotic and Finite Sample Properties. Journal of Economics, 108, 1-24. https://doi.org/10.1016/S0304-4076(01)00098-7

[18] Hadri, K. (2000) Testing for Stationarity in Heterogeneous Panel Data. Journal of Econometrics, 3, 148-161. https://doi.org/10.1111/1368-423X.00043

[19] Jalloh, B. (1998) Information Dissemination for Better Health in Africa with Particular Reference to Namibia. Journal of Documentation, 54, 244-249. https://doi.org/10.1108/EUM0000000007168

[20] Quaye, R. (1996) Assessment of Medical Technology and the Challenge for Health Reform in Africa. International Journal of Health Care Quality Assurance, 9, 38-43. https://doi.org/10.1108/09526869610109215

[21] Macnab, A.J., Stewart, D. and Gagnon, F.A. (2014) Health Promoting Schools: Initiatives in Africa. Health Education, 114, 246-259.

https://doi.org/10.1108/HE-11-2013-0057

[22] Semali, L.M. (2007) Challenges of Rebuilding Education in Crisis: Access to Universal Primary Education in Africa. In: Baker, D.P. and Wiseman, A.W., Eds., Education for All International Perspectives on Education and Society, Vol. 8, Emerald Group Publishing Limited, Bingley, 395-425.

https://doi.org/10.1016/S1479-3679(06)08014-5

[23] AAI (Africa-America Institute) (2015) State of Education in Africa Report 2015. The Africa-America Institute, New Jersey.

[24] Psacharopoulos, G. (1994) Returns to Investment in Education: A Global Update. World Development, 22, 1325-1343. https://doi.org/10.1016/0305-750X(94)90007-8

[25] Liu, F., Li, L., Zhang, Y.Q., Ngo, Q.-T. and Iqbal, W. (2021) Role of Education in Poverty Reduction: Macroeconomic and Social Determinants form Developing Econo- 
mies. Environmental Science and Pollution Research, 28, 63163-63177. https://doi.org/10.1007/s11356-021-15252-Z

[26] Mihai, M., Țițan, E. and Manea, D. (2015) Education and Poverty. Procedia Economics and Finance, 32, 855-860. https://doi.org/10.1016/S2212-5671(15)01532-4

[27] Russell, C.H. (2017) Discerning the Multiple Business Benefits of Energy Efficiency. Strategic Planning for Energy and the Environment, 6, 24-40.

[28] Louise, F.M. and Melissa Sekkel, G. (2008) Working out of Poverty: Job Creation and the Quality of Growth in Africa. World Bank, Washington DC.

[29] Santana-Gallego, M. and Fourie, J. (2020) Tourism Falls Apart: How Insecurity Affects African Tourism. Tourism Economics, Article ID: 1354816620978128. https://doi.org/10.1177/1354816620978128

[30] Brainard, L., Chollet, D. and LaFleur, V. (2007) The Tangled Web: The PovertyInsecurity Nexus. In: Brainard, L. and Chollet, D., Eds., Too Poor for Peace, Brookings Institution, Washington DC, 1-30. 